\title{
Performance-Based Selection of the Cathode Material for the Electrodeposition-Redox Replacement Process of Gold Recovery from Chloride Solutions
}

\author{
IVAN KOROLEV, KIRSI YLINIEMI, MARI LINDGREN, LEENA CARPÉN, \\ and MARI LUNDSTRÖM
}

\begin{abstract}
Recently, an emerging electrodeposition-redox replacement (EDRR) method was demonstrated to provide exceptionally efficient gold recovery from cyanide-free hydrometallurgical solutions. However, the effect of electrode material and its corrosion resistance in this process was overlooked, even though the EDRR process is carried out in extremely corrosive, acidic chloride solution that also contains significant amounts of strong oxidants, i.e., cupric ions. In the current study, nickel alloy C-2000, stainless steels 316 L and 654SMO, and grade 2 titanium were for the first time critically evaluated as potential cathode materials for EDRR. The particular emphasis was placed on better understanding of the effect of cathode substrate on the overall efficiency of the gold recovery process. The use of a multiple attribute decision-making method of material selection allowed reaching of a well-founded compromise between the corrosion properties of the electrodes and process efficiency of gold extraction. The 654SMO steel demonstrated outstanding performance among the examined materials, as it enabled gold recovery of 28.1 pet after 3000 EDRR cycles, while its corrosion rate (CR) was only $0.02 \mathrm{~mm} /$ year.
\end{abstract}

https://doi.org/10.1007/s11663-021-02239-x

(C) The Author(s) 2021

\section{INTRODUCTION}

THE recent innovation of electrodeposition-redox replacement $(E D R R)^{[1-6]}$ shows potential as a new method for the recovery of (precious) metals from hydrometallurgical solutions where their concentration is extremely low, i.e., at parts per billion to parts per million scale. All of the published articles, however, studied the phenomenon itself, mostly relying on ideal electrodes, such as platinum or glassy carbon, and topics

IVAN KOROLEV is with the Hydrometallurgy and Corrosion, Department of Chemical and Metallurgical Engineering, School of Chemical Engineering, Aalto University, Espoo, 02151, Finland, and with the Metso Outotec Research Center, Pori, 28101, Finland. KIRSI YLINIEMI is with the Department of Chemistry and Material Science, School of Chemical Engineering, Aalto University, Espoo, 02151, Finland. MARI LINDGREN is with the Metso Outotec Research Center. LEENA CARPÉN is with the Materials Performance Unit, VTT Technical Research Centre of Finland Ltd., Espoo, 02151, Finland. MARI LUNDSTRÖM is with the Hydrometallurgy and Corrosion, Department of Chemical and Metallurgical Engineering, School of Chemical Engineering, Aalto University. Contact email: mari.lundstrom@aalto.fi

Manuscript submitted January 29, 2021; accepted May 26, 2021.

Article published online July 16, 2021. such as true material selection of cathodes have not been discussed. In this article, potential electrode materials are studied for cyanide-free, chloride-based gold recovery by EDRR. On the laboratory scale, the EDRR is perceived as an efficient extraction process with strong prospects for its full-scale implementation. ${ }^{[7,8]}$ However, when a development-stage metallurgical process is being scaled-up from a laboratory to an industrial scale, it is crucial to find the most appropriate, durable construction materials because this choice will affect the efficiency, the feasibility, and even the safety of the process. ${ }^{[9-11]}$

Hydrometallurgical processes of metals recovery set high requirements for the materials of the reactors, pipelines, and other parts of the process equipment. One of the main concerns regarding electrochemical metal recovery processes is the corrosion behavior of electrode materials. In the conventional gold electrowinning that is performed in alkaline cyanide solutions, constantly applied current itself provides a cathodic protection of the electrode materials from corrosion. ${ }^{[12]}$ This allows for the usage of common stainless steels, such as 304 or $316 \mathrm{~L}$, as cathode materials in industrial gold electrowinning circuits. ${ }^{[13-15]}$ By contrast, the cyanide-free chloride technologies require more resilient materials due to the highly corrosive nature of the fluids involved in the 
process. Typical leaching solution in the gold chloride process contains 150 to $250 \mathrm{~g} / \mathrm{L}$ of chloride ions and a significant amount (up to $50 \mathrm{~g} / \mathrm{L}$ ) of strong oxidants such as $\mathrm{Cu}^{2+}$ or $\mathrm{Fe}^{3+} \cdot{ }^{[16-18]}$ Together with an acidic $\mathrm{pH}$ (below 2) and elevated temperatures, such solutions create an aggressive environment that requires exceptionally resistant materials. ${ }^{[19,20]}$ Furthermore, during the EDRR process, the applied potential switches between cathodic and open circuit values, which makes the cathode more vulnerable for corrosion compared to traditional electrowinning.

The present study focuses on identifying the material of choice for the permanent cathode blanks to be used in the EDRR process. The objective of a material selection procedure is to identify the most essential material properties for a given application and obtain their combination, satisfying the design criteria. ${ }^{[21,22]}$ The problem of selecting the appropriate material and eliminating unsuitable ones based on several properties is solved by applying one of the multiple attribute decision-making methods. Over the decades of research, a number of methods were developed to ensure that the material selected suits the needs of the process design, maximizing its performance and minimizing its cost. ${ }^{[23-25]}$ Among these methods, the most popular are the analytical hierarchy process (AHP),${ }^{[26,27]}$ the multicriteria optimization and compromise solution (VIKOR), ${ }^{[28,29]}$ the technique for order performance by similarity to ideal solution (TOPSIS) ${ }^{[30,31]}$ or combinations of multiple decision making methods. ${ }^{[32,33]} \mathrm{In}$ the current study, a hybrid approach merging the AHP and TOPSIS, as described by Rao and Davim, ${ }^{[34]}$ was used to rank the alternatives and make the conclusive decision on material selection. This method employs the AHP to determine in a systematic way the individual weights of each attribute and the TOPSIS technique to rank the alternative materials in order of preference.

The right choice of the engineering materials plays an important role in the design of a new product or process. With the results of experiments in actual process conditions accompanied by established material selection methods, an informed choice of the optimum electrode material can be made, which will advance the EDRR process to higher technology readiness levels. ${ }^{[35]}$ In this article, an extensive corrosion study of four different alloys (i.e., stainless steels 316L and 654SMO, nickel alloy C-2000, and commercially pure titanium TA2) was combined with the gold recovery experiments to provide the necessary input for the AHP-TOPSIS decision-making method. The results showed that the 654SMO stainless steel is the optimum cathode material for the EDRR from both corrosion resistance and gold recovery perspectives, while the $316 \mathrm{~L}$ steel did not withstand corrosion in the process solution and was not capable of recovering gold on the cathode.

\section{EXPERIMENTAL}

\section{A. Materials}

Four alloys were examined as potential cathode materials, i.e., nickel-chromium-molybdenum alloy C-2000 (UNS N06200), low-carbon chromium-nickel-molybdenum austenitic stainless steel 316L (UNS S31603), high-nitrogen superaustenitic stainless steel 654SMO (UNS S32654), and unalloyed Grade 2 titanium, TA2 (UNS R50400). The chemical composition of the material samples (Table I) was analyzed with the Niton XL3t X-ray fluorescent spectrometer (Thermo Fischer Scientific (Waltham, MA)) and is consistent with the specifications of these materials. ${ }^{[36]}$

All experiments were performed in a naturally aerated pregnant leach solution originated from cupric chloride leaching of a gold ore. The composition of the solution, as well as its $\mathrm{pH}$ and redox potential (Table II), is typical for such a process. ${ }^{[37-39]}$ Solution samples were analyzed by inductively coupled plasma-optical emission spectroscopy (ICP-OES; Thermo Scientific iCap 6000 ), and the gold content was additionally measured by mass-spectrometry (ICP-MS; Thermo Scientific iCap Q).

Table I. Composition of Cathode Materials (Weight Percent)

\begin{tabular}{|c|c|c|c|c|c|c|c|c|c|}
\hline Material & $\mathrm{Fe}$ & $\mathrm{Cr}$ & $\mathrm{Ni}$ & Mo & $\mathrm{Mn}$ & $\mathrm{Cu}$ & $\mathrm{C}$ & $\mathrm{N}$ & $\mathrm{Ti}$ \\
\hline \multicolumn{10}{|l|}{$316 \mathrm{~L}$} \\
\hline analyzed & 66.9 & 17.3 & 11.0 & 2.3 & 1.7 & 0.4 & $*$ & $*$ & - \\
\hline standard & bal & 16 to 18 & 10 to 14 & 2 to 3 & $\leq 2.0$ & - & $\leq 0.03$ & $\leq 0.01$ & - \\
\hline \multicolumn{10}{|l|}{ 654SMO } \\
\hline analyzed & 42.2 & 24.1 & 22.1 & 7.3 & 3.6 & 0.4 & $*$ & $*$ & - \\
\hline standard & bal & 24 to 25 & 21 to 23 & 7 to 8 & 2 to 4 & 0.3 to 0.6 & $\leq 0.02$ & 0.45 to 0.55 & - \\
\hline \multicolumn{10}{|l|}{ C-2000 } \\
\hline analyzed & 1.5 & 22.7 & 58.6 & 15.3 & 0.3 & 1.7 & $*$ & $*$ & - \\
\hline standard & $\leq 3.0$ & 22 to 24 & bal & 15 to 17 & $\leq 0.5$ & 1.3 to 1.9 & $\leq 0.01$ & - & - \\
\hline \multicolumn{10}{|l|}{ TA2 } \\
\hline analyzed & - & - & - & - & - & - & $*$ & $*$ & 99.8 \\
\hline standard & $\leq 0.3$ & - & - & - & - & - & $\leq 0.08$ & $\leq 0.03$ & $\geq 98.9$ \\
\hline
\end{tabular}

*The element cannot be measured with X-ray fluorescence. 
Table II. Parameters of Process Solution

\begin{tabular}{lcccccc}
\hline $\mathrm{Au}(\mathrm{mg} / \mathrm{L})$ & $\mathrm{Cu}(\mathrm{g} / \mathrm{L})$ & $\mathrm{Fe}(\mathrm{g} / \mathrm{L})$ & $\mathrm{Na}(\mathrm{g} / \mathrm{L})$ & $\mathrm{Cl}(\mathrm{g} / \mathrm{L})$ & $\mathrm{pH}$ & Redox Potential $(\mathrm{mV}$ Pt $v s \mathrm{Ag} / \mathrm{AgCl})$ \\
\hline 3.13 & 31.6 & 0.94 & 84.4 & 208 & 1.29 & 647 \\
\hline
\end{tabular}

\section{B. Corrosion Measurements}

The rate of corrosion was estimated by exposing pieces of metal samples to the process solution (Table II) for 50 days at ambient temperature $\left(21{ }^{\circ} \mathrm{C}\right.$ to $23{ }^{\circ} \mathrm{C}$ ) and at $85{ }^{\circ} \mathrm{C}$. Before the experiments, the specimens for corrosion measurements were cut into pieces of rectangular shape with an average surface area of $25 \mathrm{~cm}^{2}$, wet polished with $\mathrm{SiC}$ paper to 1200 grit, cleaned ultrasonically in deionized water, rinsed with ethanol, and air dried. Each of the specimens was measured with a vernier caliper, weighed to a precision of $0.1 \mathrm{mg}$, and immersed in a glass vessel filled with process solution so that the ratio between the solution volume and the surface area of the specimen was $40 \mathrm{~mL} /$ $\mathrm{cm}^{2}$. At the end of experiments, the surface of the samples was cleaned of corrosion products according to the procedures described in the ASTM standard ${ }^{[40]}$ and weighed to calculate the corrosion rate $(\mathrm{CR}, \mathrm{mm} / \mathrm{year})$ :

$$
\mathrm{CR}=\frac{87,600}{A \cdot \rho \cdot t} \cdot \Delta m
$$

where $A$ is the surface area of the sample, $\rho$ is the density of the alloy, and $t$ is the immersion time. Three parallel sets of specimens were subjected to immersion experiments; the average $\mathrm{CR}$ was calculated and the reproducibility was evaluated.

A Gamry Reference 600 potentiostat/galvanostat (Gamry Instruments (Warminster, PA)) was used to carry out the electrochemical corrosion measurements. All experiments were performed at three different temperatures: $25{ }^{\circ} \mathrm{C}, 55^{\circ} \mathrm{C}$, and $85{ }^{\circ} \mathrm{C}$. In order to minimize the effect of crevice corrosion and keep the solution temperature constant, the measurements were run in a water-jacketed Avesta cell ${ }^{[41]}$ with coiled Pt wire as the counter electrode and saturated calomel electrode $\left(\mathrm{SCE} ; E_{h}^{0}=241 \mathrm{mV}\right)$ as the reference electrode.

Cyclic potentiodynamic polarization measurements were recorded by sweeping the potential in the anodic direction at a scan rate of $0.1667 \mathrm{mV} / \mathrm{s}$ starting from $200 \mathrm{mV}$ vs open circuit potential (OCP) until the current density reached $10 \mathrm{~mA} / \mathrm{cm}^{2}$, after which the direction of the scan was reversed. The initial cathodic polarization was performed in order to analyze the activity region of the polarization curves and evaluate the Tafel coefficients by numerical fitting of the Butler-Volmer equation: ${ }^{[42,43]}$

$$
i=i_{\text {corr }} \cdot\left\{\exp \left(\frac{\eta}{b_{\mathrm{a}}}\right)-\exp \left(-\frac{\eta}{b_{\mathrm{c}}}\right)\right\}
$$

where $i_{\text {corr }}$ is the corrosion current density, $\eta$ is the overpotential, and $b_{a}$ and $b_{c}$ are the anodic and cathodic Tafel coefficients, respectively.
In the linear polarization resistance (LPR) experiments, the samples were polarized from -10 to +10 $\mathrm{mV}$ vs OCP with a scan rate of $0.1 \mathrm{mV} / \mathrm{s}$. The measurements were repeated three times, and the average values of polarization resistance $R_{\mathrm{p}}$ were then used to calculate the corrosion current density $i_{\text {corr }}$ via the Stern-Geary equation: ${ }^{[44]}$

$$
i_{\text {corr }}=\frac{b_{\mathrm{a}} \cdot b_{\mathrm{c}}}{\left(b_{\mathrm{a}}+b_{\mathrm{c}}\right) \cdot \ln 10} \cdot \frac{1}{R_{\mathrm{p}}}
$$

The rate of corrosion is related to the corrosion current density according to Eq. [4]:

$$
\mathrm{CR}=\frac{3.27 \cdot 10^{-3} \cdot \mathrm{EW}}{\rho} \cdot i_{\mathrm{corr}}
$$

where EW is the equivalent weight of the alloy. ${ }^{[45]}$

The electrochemical impedance spectroscopy (EIS) measurements were carried out in galvanostatic mode at the open circuit potential with a $10 \mu \mathrm{A}$ root mean square amplitude of applied AC current. The data were recorded in a frequency range from $1 \mathrm{MHz}$ to $10 \mathrm{mHz}$ with a logarithmic sweeping frequency of 9 points per decade. A capacitive coupling with Pt wire and $1-\mu \mathrm{F}$ capacitor was connected in parallel to the reference electrode in order to avoid phase shifts at high frequencies during the EIS measurements. ${ }^{[46,47]}$ The data analysis and equivalent circuit modeling were performed with Gamry Echem Analyst 6.25 software.

\section{EDRR Experiments}

The EDRR method ${ }^{[48]}$ consists of two consecutive steps - electrodeposition (ED) and redox replacement (RR) - that are continuously repeated after each other $N$ times. During the ED step, copper is potentiostatically deposited on the working electrode surface at potential $E_{\mathrm{ED}}$ for a predefined time $t_{\mathrm{ED}}$. In the RR step, the cell is switched to open circuit conditions for a time $t_{\mathrm{RR}}$ to allow for $\mathrm{RR}$ between gold and copper. The actual values of the EDRR process parameters $E_{\mathrm{ED}}$, $t_{\mathrm{ED}}, t_{\mathrm{RR}}$, and $N$ are shown in Table III.

The EDRR experiments were performed in the standard three-electrode cell with cathodes made of polished metal samples (surface area: $1 \mathrm{~cm}^{2}$ ); iridium-tantalum mixed oxide-coated titanium mesh was used as the anode and SCE as the reference electrode. Measurements were controlled by the VersaStat $3 \mathrm{~F}$ potentiostat (Princeton Applied Research).

Gold deposits obtained on the cathodes in the EDRR experiments were examined using a JEOL* JSM-6490LV scanning electron microscope (SEM) equipped with an energy dispersive spectrometer 
Table III. Experimental Design for EDRR Measurements

\begin{tabular}{|c|c|c|c|c|}
\hline Cathode Material & $E_{\mathrm{ED}}(\mathrm{mV} v s \mathrm{SCE})$ & $t_{\mathrm{ED}}(\mathrm{s})$ & $t_{\mathrm{RR}}(\mathrm{s})$ & $N$ \\
\hline $316 \mathrm{~L}$ & -820 & 7 & 60 & 3000 \\
\hline 654SMO & -410 & 7 & 60 & 3000 \\
\hline C-2000 & -390 & 7 & 60 & 3000 \\
\hline TA2 & -340 & 7 & 60 & 3000 \\
\hline
\end{tabular}

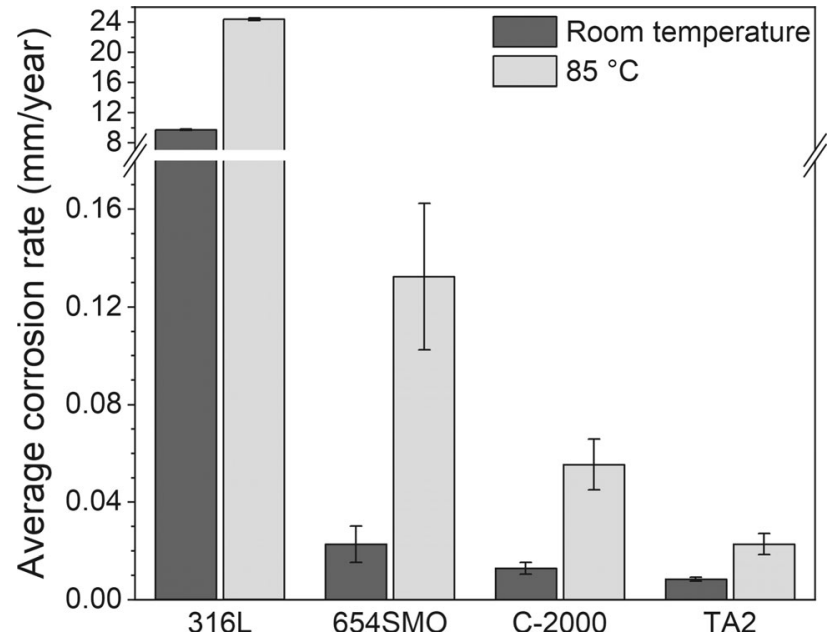

Fig. 1-Rates of corrosion calculated from the weight loss during the immersion experiments.

(EDS) and Aztec software, both from Oxford Instruments (Oxford, United Kingdom). The imaging and EDS analyses were performed under routine conditions using $15-\mathrm{kV}$ acceleration voltage and 1-nA beam current.

\section{RESULTS AND DISCUSSION}

\section{A. Corrosion Behavior}

In the immersion experiments, none of the materials showed significant uniform corrosion; hence, the values calculated via Eq. [1] should be considered only as a relative measure of the materials' corrosion resistance rather than exact values of the rate of uniform corrosion

*JEOL is a trademark of JEOL, Tokyo.

(Figure 1). It must be noted, though, that the $316 \mathrm{~L}$ stainless steel suffered from severe pitting corrosion in the process solution, and after 50 days of the immersion experiment, the samples of $316 \mathrm{~L}$ steel were dissolved completely. With an exception for the $316 \mathrm{~L}$ steel, at room temperature, all studied materials showed CRs under $0.1 \mathrm{~mm} /$ year and, thus, could be considered as corrosion resistant. Although the increase in temperature from ambient to $85^{\circ} \mathrm{C}$ accelerated the corrosion of all the studied materials, for the C-2000 and TA2
Table IV. Polarization Resistance $R_{\mathrm{p}}(\mathrm{k} \Omega)$ of Materials Investigated at Different Temperatures

\begin{tabular}{lccc}
\hline Material & $25{ }^{\circ} \mathrm{C}$ & $55^{\circ} \mathrm{C}$ & $85^{\circ} \mathrm{C}$ \\
\hline $316 \mathrm{~L}$ & $0.044 \pm 0.001$ & $0.019 \pm 0.001$ & $0.008 \pm 0.001$ \\
654SMO & $21.7 \pm 0.4$ & $4.7 \pm 0.1$ & $2.9 \pm 0.1$ \\
C-2000 & $16.9 \pm 0.2$ & $11.4 \pm 0.1$ & $2.2 \pm 0.1$ \\
TA2 & $81.8 \pm 5.7$ & $73.6 \pm 3.8$ & $12.3 \pm 0.2$ \\
\hline
\end{tabular}

samples, the CRs remained below $0.1 \mathrm{~mm} /$ year. Similar findings were reported in previous corrosion studies in the environments relevant to the chloride leaching of gold. ${ }^{[49,50]}$

The LPR method is an essentially nondestructive technique for estimation of the uniform $\mathrm{CR}$ of the material. It is based on the fact that near the corrosion potential, $E_{\text {corr }}$, current density is linearly dependent on the overpotential ${ }^{[51]}$; then, the polarization resistance $R_{\mathrm{p}}$ of the system is equal to the slope of the current-potential line. The $R_{\mathrm{p}}$ values obtained from the LPR measurements at different temperatures are presented in Table IV. As the temperature of the solution increased, the polarization resistance values decreased, indicating accelerated corrosion at higher temperatures. This observation is in line with the results of the gravimetric experiments, as $316 \mathrm{~L}$ clearly showed the lowest polarization resistance (i.e., most prone to corrosion) while the other samples demonstrated reasonably high $R_{\mathrm{p}}$ values. Furthermore, the obtained values are close to those reported for the same materials in acidic chloride solutions of similar concentrations. ${ }^{[52-54]}$

Cyclic polarization (CPP) is used to determine the susceptibility of the studied materials to the localized pitting corrosion. ${ }^{[55]}$ Analysis of the polarization curves in Figure 2 reveals different behaviors of the examined materials with regard to the localized corrosion.

For the $316 \mathrm{~L}$ steel, even a small anodic overpotential was sufficient to reach the pitting potential (i.e., current density of $10 \mathrm{~mA} / \mathrm{cm}^{2}$ ). During the reverse scan, a hysteresis loop was observed, indicating stable propagation of corrosion. ${ }^{[56]}$ In the case of the 654SMO alloy, the corrosion system was activation controlled. At the overpotential of approximately 80 to $90 \mathrm{mV}$, the passivation of the alloy surface occurred, bringing it to the condition of nearly complete absence of corrosion. The increase of the current density as the anodic polarization progressed after $E_{\mathrm{tr}}=250 \mathrm{mV}$ indicates the transpassivity region, which in the absence of the 

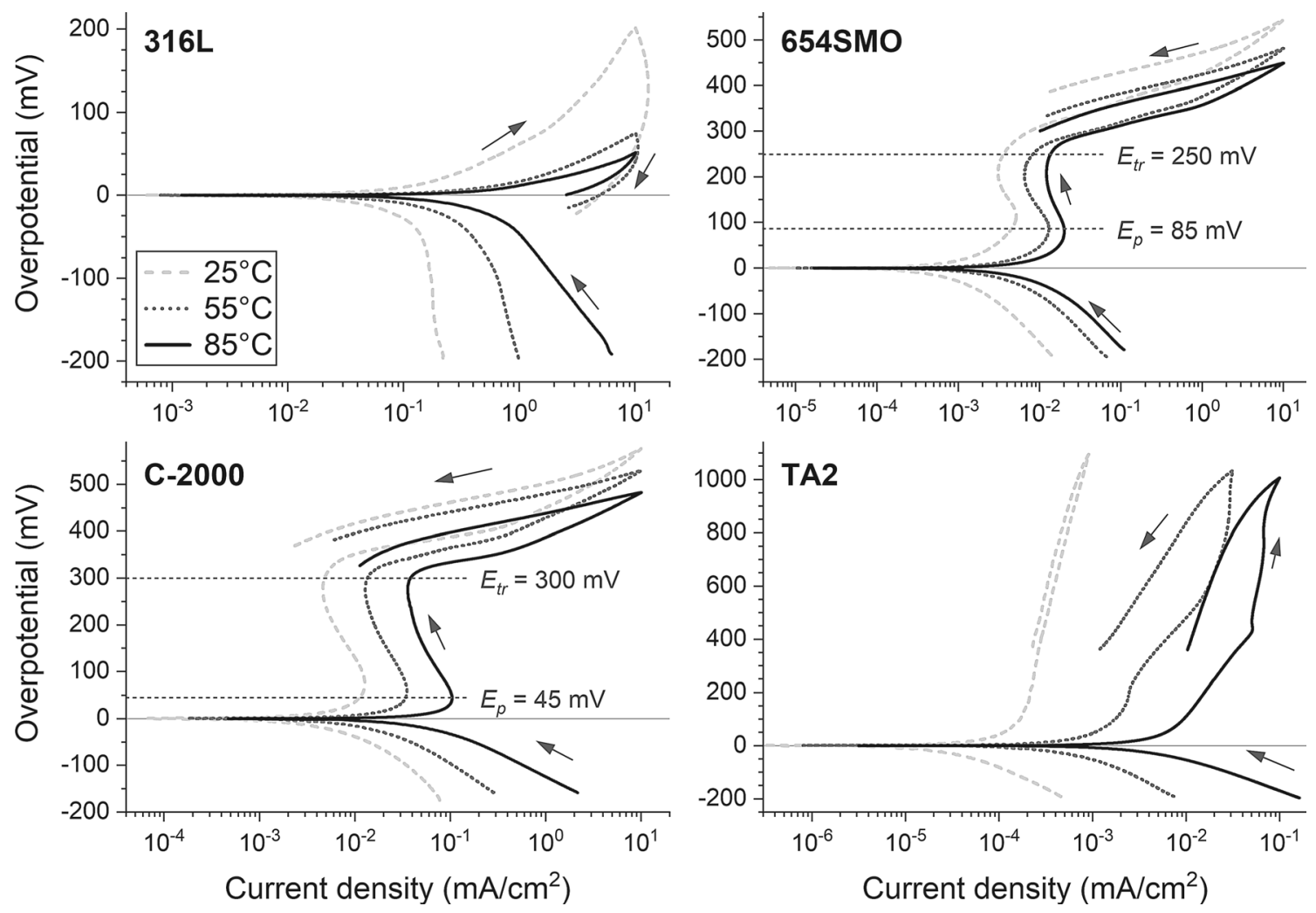

Fig. 2-Polarization curves of the cathode materials.

localized corrosion corresponds to another oxidation process, e.g., oxygen evolution. ${ }^{[57]}$ Similar behavior was observed for alloy C-2000, with a slightly greater passivity region between $E_{\mathrm{p}}=45 \mathrm{mV}$ and $E_{\mathrm{tr}}=300$ $\mathrm{mV}$. This is consistent with the results obtained by Zhang et al.$^{[58]}$ in $5 \mathrm{M} \mathrm{NaCl}$ solutions. Titanium, on the other hand, did not show a clear activity region in the anodic scan. Passivation of the titanium electrode surface can be linked to the formation of insulating oxide film that prevents corrosion. ${ }^{[59,60]}$ The change of the apparent slope of the polarization curve around 400 $\mathrm{mV}$ indicates the beginning of the oxygen evolution; however, the current density did not increase significantly in the studied potential range.

The CRs determined by both methods, i.e., by fitting CPP curves to the Butler-Volmer equation (Eq. [2]) and using the $R_{\mathrm{p}}$ value from the LPR measurements in the Stern-Geary equation (Eq. [3]), showed good agreement with the results of the immersion tests (Table V). The effect of temperature $T$ on the CR of material is expressed by the Arrhenius equation:

$$
\mathrm{CR}=A \cdot \exp \left(-\frac{E_{\mathrm{a}}}{R T}\right)
$$

where $A$ is a constant, $E_{a}$ is the activation energy, and $\mathrm{R}=8.31 \mathrm{~J} / \mathrm{mol} \cdot \mathrm{K}$ is the universal gas constant.

The activation energy (calculated as the slope of a straight line on the $\log \mathrm{CR}$ vs $1 / T$ plot; Figure 3) represents the minimum amount of energy required for the initiation of the corrosion process. It has been suggested that the activation energy of corrosion can be used as a performance indicator for material selection. ${ }^{[61]}$ For the $316 \mathrm{~L}$ steel, the activation energy is below $20 \mathrm{~kJ} / \mathrm{mol}$ (Table $\mathrm{V}$ ), which indicates a fast, diffusion-limited dissolution process. ${ }^{[62]}$ On the other hand, high activation energies $(>40 \mathrm{~kJ} / \mathrm{mol})$ are typical for surface processes controlled by the rate of chemical reaction and, hence, more corrosion-resistant materials. The alloys $654 \mathrm{SMO}, \mathrm{C}-2000$, and TA2 are presumed to be under mixed control corrosion.

\section{B. EIS Measurements}

The impedance spectroscopy provides a detailed insight of the surface processes at OCPs. Nyquist plots recorded in the process solution at different temperatures are shown in Figure 4. It can be observed from the shape of the Nyquist plot that the impedance response of the electrodes was different for corroding and passivating systems.

The plots in Figure 4 for 316L material (which suffered the most intensive corrosion in immersion experiments) were characterized by a high-frequency capacitive loop and a low-frequency inductive loop, which are typical features of the steel dissolution in acidic environments. ${ }^{[63,64]}$ The high-frequency capacitive loop is attributed to the interfacial charge-transfer reaction, and the slightly depressed nature of the capacitive semicircles is due to the roughness and heterogeneity of the steel electrode surface. ${ }^{[65]}$ An inductive loop that was observed at low frequencies indicates the evolution of the system during the 
Table V. Summary of CR Estimates for Studied Materials Obtained With Different Methods

\begin{tabular}{|c|c|c|c|c|c|}
\hline \multirow[b]{2}{*}{ Material } & \multirow[b]{2}{*}{$T\left({ }^{\circ} \mathrm{C}\right)$} & \multicolumn{3}{|c|}{ CR (mm/year), Derived from } & \multirow[b]{2}{*}{$E_{\mathrm{a}}(\mathrm{kJ} / \mathrm{mol})$} \\
\hline & & Weight Loss & LPR & $\mathrm{CPP}$ & \\
\hline \multirow[t]{3}{*}{$316 \mathrm{~L}$} & 25 & $9.7(0.9 \text { pct })^{*}$ & $13.0(1.8 \mathrm{pct})$ & 4.3 & 16.3 \\
\hline & 55 & - & $17.1(3.0 \mathrm{pct})$ & 10.0 & - \\
\hline & 85 & $24.4(0.7 \mathrm{pct})$ & $35.8(5.2 \mathrm{pct})$ & 17.2 & - \\
\hline \multirow[t]{3}{*}{ 654SMO } & 25 & $0.023(8.2 \mathrm{pct})$ & $0.020(1.8 \mathrm{pct})$ & 0.014 & 28.2 \\
\hline & 55 & - & $0.089(0.5 \mathrm{pct})$ & 0.062 & - \\
\hline & 85 & $0.132(5.7 \mathrm{pct})$ & $0.132(0.9 \mathrm{pct})$ & 0.107 & - \\
\hline \multirow[t]{3}{*}{ C-2000 } & 25 & 0.013 (4.8 pct) & $0.018(1.5 \mathrm{pct})$ & 0.007 & 24.1 \\
\hline & 55 & - & $0.018(0.5 \mathrm{pct})$ & 0.020 & - \\
\hline & 85 & $0.055(4.7 \mathrm{pct})$ & 0.067 (6.3 pct) & 0.063 & - \\
\hline \multirow[t]{3}{*}{ TA2 } & 25 & 0.008 (2.4 pct) & $0.002(7.0 \mathrm{pct})$ & 0.002 & 35.8 \\
\hline & 55 & - & $0.004(5.2 \mathrm{pct})$ & 0.005 & - \\
\hline & 85 & $0.023(4.8 \mathrm{pct})$ & 0.026 (1.6 pct) & 0.042 & - \\
\hline
\end{tabular}

*Percentages in parentheses show the standard deviation.

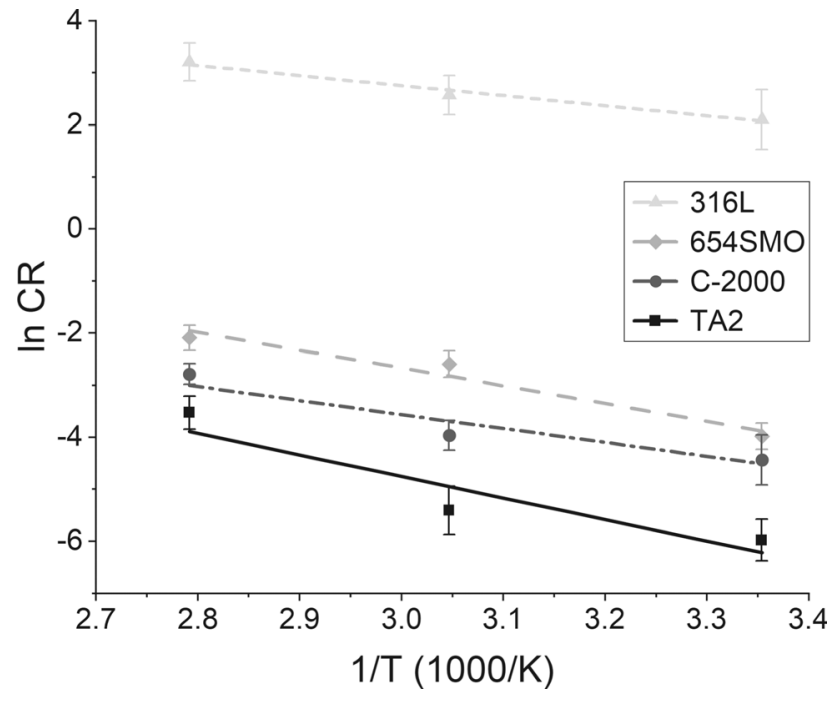

Fig. 3-Arrhenius plot for determination of the activation energy of corrosion.

measurement. In the case of the $316 \mathrm{~L}$ steel, this change is related to the dissolution of the electrode material and relaxation of the adsorbed intermediate species from its surface. ${ }^{[66,67]}$ It is seen that an increase of solution temperature decreased the diameter of the semicircle, therefore intensifying the dissolution of steel. This is consistent with the polarization curves shown in Figure 2. The equivalent circuit model for the EIS data fitting is shown in Figure 5(a), and the fitted results are given in Table VI.

For the materials less affected by corrosion (Figure 4), the impedance spectra exhibited a temperature-dependent capacitive response with two time constants, i.e., depressed semicircle at high frequencies and a somewhat unfinished capacitive arc in the low-frequency range. Such behavior is often considered as the response of an inhomogeneous film composed of a compact inner barrier layer and a loose permeable porous outer layer. ${ }^{[68]}$ It seems likely that the outer layer is formed of the same species (e.g., metal oxides or hydroxides) as the inner layer but contains microscopic pores, which may be filled by electrolyte solution or some precipitated/hydrated compounds. An equivalent circuit shown in Figure 5(b) was previously reported for the interpretation of the observed phenomena. ${ }^{[69,70]}$

In general, the impedance of all investigated systems decreased with temperature, which is consistent with the results from polarization measurements and general corrosion experiments (Table V). Furthermore, the sum of resistive contributions $R_{1}+R_{2}$ represents the polarization resistance $R_{\mathrm{p}}$ and provides values close to those obtained from the LPR measurements (Table IV). The resistance at frequencies above approximately 100 $\mathrm{kHz}$ corresponds to the uncompensated ohmic resistance of the solution $R_{\mathrm{s}}$, which remains nearly constant $(\approx 2.3 \Omega)$ in all the experiments.

The values of the constant phase element constant $Q$ can be used to estimate the effective capacitance $C_{\text {eff }}$ of the passive layer: $:^{[71,72]}$

$$
C_{\text {eff }}=Q^{\frac{1}{\alpha}} \cdot R^{\frac{1-\alpha}{\alpha}}
$$

According to the Helmholtz model, the capacitance is inversely proportional to a passive layer thickness $d$; thus, the capacitive response of the materials can give an indication of how the thickness of the passive film changes with temperature: ${ }^{[73]}$

$$
d=\frac{\varepsilon \varepsilon_{0} S}{C_{\text {eff }}}
$$

where $\varepsilon_{0}=8.85 \cdot 10^{-12} \mathrm{~F} / \mathrm{m}^{2}, \varepsilon$ is the relative permittivity of the passive layer, and $S$ is the sample surface area exposed to the solution.

It is difficult to obtain an exact thickness of the passive film from the capacitance values due to its irregular porous structure. Furthermore, the relative permittivity values of passive films are not universally established and may vary depending on the electrolyte 

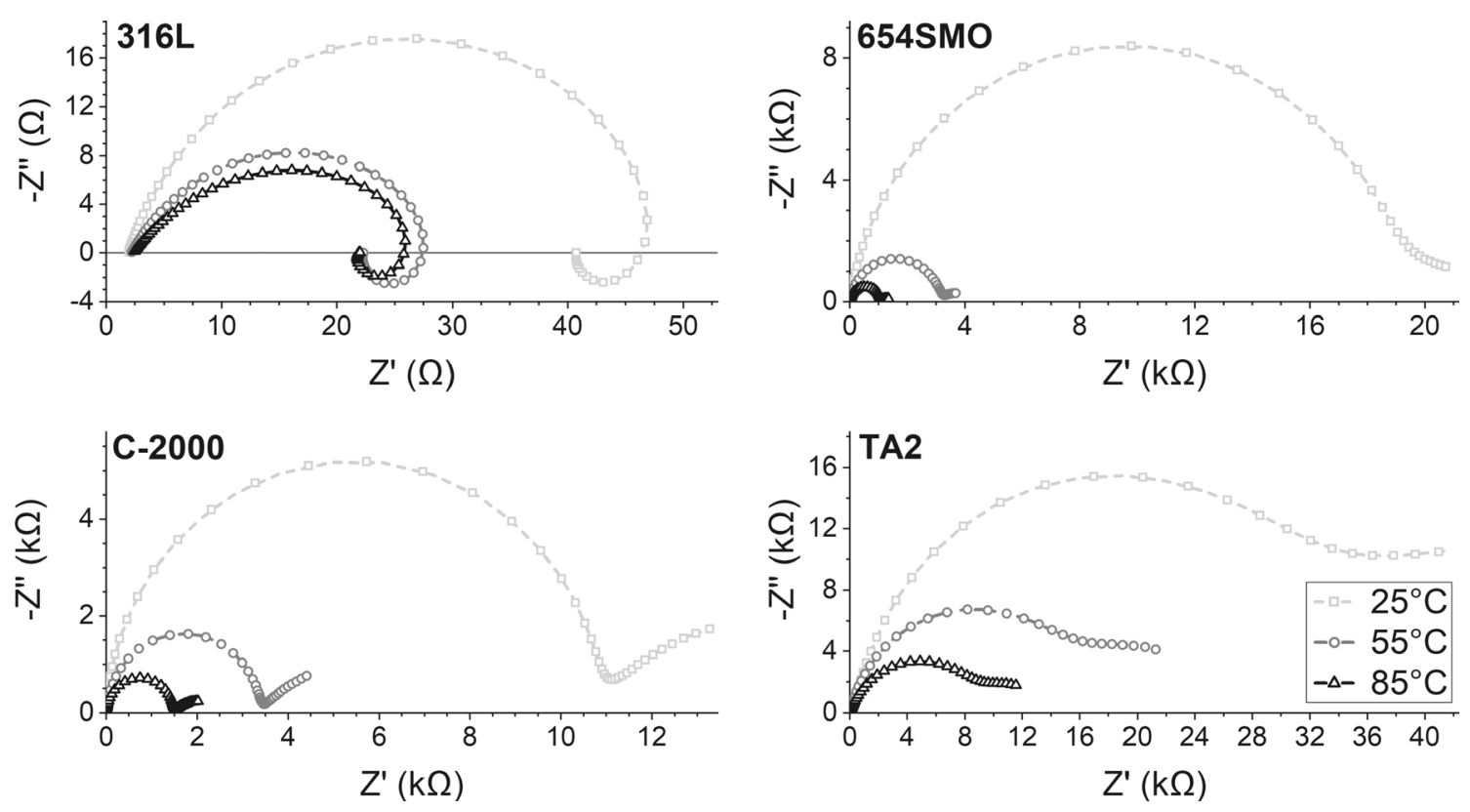

Fig. 4-Experimental EIS data (symbols) and corresponding fitted model (lines).

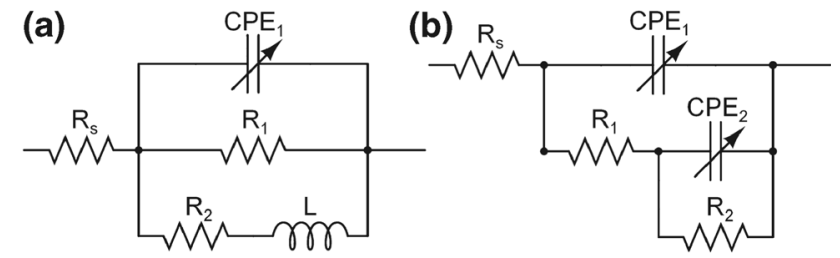

Fig. 5-Equivalent circuit models used for (a) corroding and (b) passivated electrodes.

composition and temperature, although a number of sources cited values of $\varepsilon=15.6$ for austenitic stainless steels, ${ }^{[74,75]} \varepsilon \approx 12$ for nickel-based alloys, ${ }^{[76,77]}$ and $\varepsilon$ $\approx 25$ for amorphous titanium oxide films. ${ }^{[78,79]} \mathrm{Nev-}$ ertheless, the values presented in Table VII demonstrate a clear trend in passive film deterioration at higher temperature and are of the same order of magnitude as previously reported in the literature results. $^{[80-82]}$

The understanding of the structure of the electrode/electrolyte interface is especially important in the context of the EDRR process development. For instance, in the acidic chloride solution used in the current study, the thickest barrier oxide layer among the investigated materials was observed at the TA2 cathode (approximately 4 to $8 \mathrm{~nm}$ ), which implies its superior corrosion resistance. Simultaneously, the associated resistance of the oxide layer $R_{2}$ (Table VI) decreased as the temperature of solution increased, which indicates the possible occurrence of the defects in the barrier layer. The decrease of the passive layer thickness with temperature leads to a growing susceptibility to corrosion that is corroborated by the results of polarization measurements (Table V). Similar observations are valid for the C-2000 alloy and 654SMO steel.

\section{Material Performance in the EDRR Process}

To determine whether the choice of the cathode material affects the performance of the gold recovery process, a series of the EDRR experiments with the industrial process solution was performed. The duration of the ED and RR steps, as well as the number of cycles (Table III), is based on the results of the process optimization studies reported previously, ${ }^{[83,84]}$ whereas the deposition potential $E_{\mathrm{ED}}$ depends on the cathode material and has been identified from the cyclic voltammetry (CV) measurements (Figure 6).

Two important parameters affecting the overall efficiency of the EDRR process defined from the CV are the open circuit potential $E_{\mathrm{OC}}$ and deposition potential $E_{\mathrm{ED}}$. While the open circuit potential $E_{\mathrm{OC}}$ is clearly defined as the potential at which the current density is zero, the deposition potential $E_{\mathrm{ED}}$ is not that obvious from the $\mathrm{CV}$. Its value is chosen to be slightly more negative than the onset potential $E_{\mathrm{Cu}+/ \mathrm{Cu}}$ of copper deposition to account for kinetic effects and possible variations of the solution composition during the process. It is known from previous works ${ }^{[84,85]}$ that the larger difference between $E_{\mathrm{OC}}$ and $E_{\mathrm{Cu}+/ \mathrm{Cu}}$ provides a wider operating window, which is preferred for the EDRR process. From Figure 6, it can be observed that these two potentials were closest when the $316 \mathrm{~L}$ stainless steel was used as the cathode, while the biggest difference was found in the case of the 654SMO steel, which makes it more beneficial for the EDRR.

The gold and copper recoveries were calculated from the solution analyses before and after the EDRR experiments and are summarized in Table VIII, which includes for reference the benchmark experiment with a platinum electrode. Although the highest gold recovery was achieved with the $316 \mathrm{~L}$ steel electrode, none of it was found on the cathode surface. This is directly 
Table VI. Impedance Parameters of Equivalent Circuit Models Fitted to Experimental EIS Data

\begin{tabular}{|c|c|c|c|c|c|c|c|c|c|c|}
\hline Material & $T\left({ }^{\circ} \mathrm{C}\right)$ & $R_{\mathrm{s}}(\Omega)$ & $Q_{1}\left(\mu \mathrm{S} \cdot \mathrm{s}^{n}\right)$ & $\alpha_{1}$ & $R_{1}(\mathrm{k} \Omega)$ & $Q_{2}\left(\mathrm{mS} \cdot \mathrm{s}^{n}\right)$ & $\alpha_{2}$ & $R_{2}(\mathrm{k} \Omega)$ & $L(\mathrm{H})$ & $\chi^{2} \cdot 10^{3}$ \\
\hline \multirow[t]{3}{*}{$316 \mathrm{~L}$} & 25 & 2.0 & 200.7 & 0.80 & 0.049 & - & - & 0.193 & 16.7 & 0.63 \\
\hline & 55 & 2.2 & 578.1 & 0.67 & 0.028 & - & - & 0.068 & 6.4 & 6.30 \\
\hline & 85 & 2.4 & 1041.0 & 0.57 & 0.028 & - & - & 0.064 & 4.3 & 0.05 \\
\hline \multirow[t]{3}{*}{ 654SMO } & 25 & 2.2 & 25.5 & 0.91 & 19.8 & 19.7 & 0.81 & 3.4 & - & 3.31 \\
\hline & 55 & 2.5 & 29.6 & 0.92 & 3.2 & 24.7 & 0.78 & 0.8 & - & 0.81 \\
\hline & 85 & 2.4 & 31.2 & 0.93 & 1.1 & 24.7 & 0.69 & 0.3 & - & 0.36 \\
\hline \multirow[t]{3}{*}{ C-2000 } & 25 & 2.6 & 10.7 & 0.95 & 11.1 & 19.4 & 0.81 & 4.0 & - & 1.86 \\
\hline & 55 & 2.2 & 11.9 & 0.96 & 3.4 & 10.4 & 0.66 & 2.7 & - & 2.44 \\
\hline & 85 & 2.5 & 13.1 & 0.97 & 1.5 & 10.5 & 0.55 & 1.1 & - & 3.82 \\
\hline \multirow[t]{3}{*}{ TA2 } & 25 & 2.1 & 87.4 & 0.74 & 47.1 & 24.6 & 0.99 & 19.4 & - & 1.39 \\
\hline & 55 & 2.3 & 156.3 & 0.71 & 39.2 & 37.4 & 0.98 & 22.1 & - & 2.48 \\
\hline & 85 & 2.2 & 261.8 & 0.79 & 10.1 & 41.2 & 0.96 & 2.4 & - & 0.04 \\
\hline
\end{tabular}

Table VII. Estimated Capacitance and Thickness of Passive Layer on Noncorroding Materials

\begin{tabular}{lccccc}
\hline Material & $T\left({ }^{\circ} \mathrm{C}\right)$ & $C_{\text {eff1 }}(\mu \mathrm{F})$ & $d_{1}(\mu \mathrm{m})$ & $C_{\text {eff2 }}(\mathrm{mF})$ & $d_{2}(\mathrm{~nm})$ \\
\hline 654SMO & 25 & 23.8 & 5.8 & 51.7 & 2.7 \\
& 55 & 23.9 & 5.8 & 57.9 & 2.4 \\
& 85 & 24.3 & 5.7 & 64.2 & 2.2 \\
C-2000 & 25 & 9.5 & 11.2 & 52.4 & 2.0 \\
& 55 & 10.3 & 10.3 & 56.9 & 1.9 \\
& 85 & 11.3 & 9.4 & 76.7 & 1.4 \\
TA2 & 25 & 144.2 & 1.5 & 26.8 & 8.3 \\
& 55 & 331.1 & 0.7 & 43.3 & 5.1 \\
& 85 & 338.9 & 0.7 & 50.7 & 4.4 \\
\hline
\end{tabular}

related to the vigorous corrosion of the $316 \mathrm{~L}$ steel, which releases a significant amount of ferrous ions that can react with dissolved gold causing its precipitation from the solution. ${ }^{[85,86]}$ The increased concentration of iron in the solution after the experiment also reinforces this hypothesis. The SEM image of the 316L steel cathode after 3000 cycles of EDRR (Figure 7(a)) shows a severely etched surface and clear signs of pitting corrosion; however, the EDS did not detect any significant amount of recovered gold.

The 654SMO and TA2 cathodes demonstrated gold recovery close to the maximum achieved with the platinum working electrode. The morphology of the obtained deposit is also very similar (Figures 7(b) and (d)) to the fine-grained gold particles covering the area
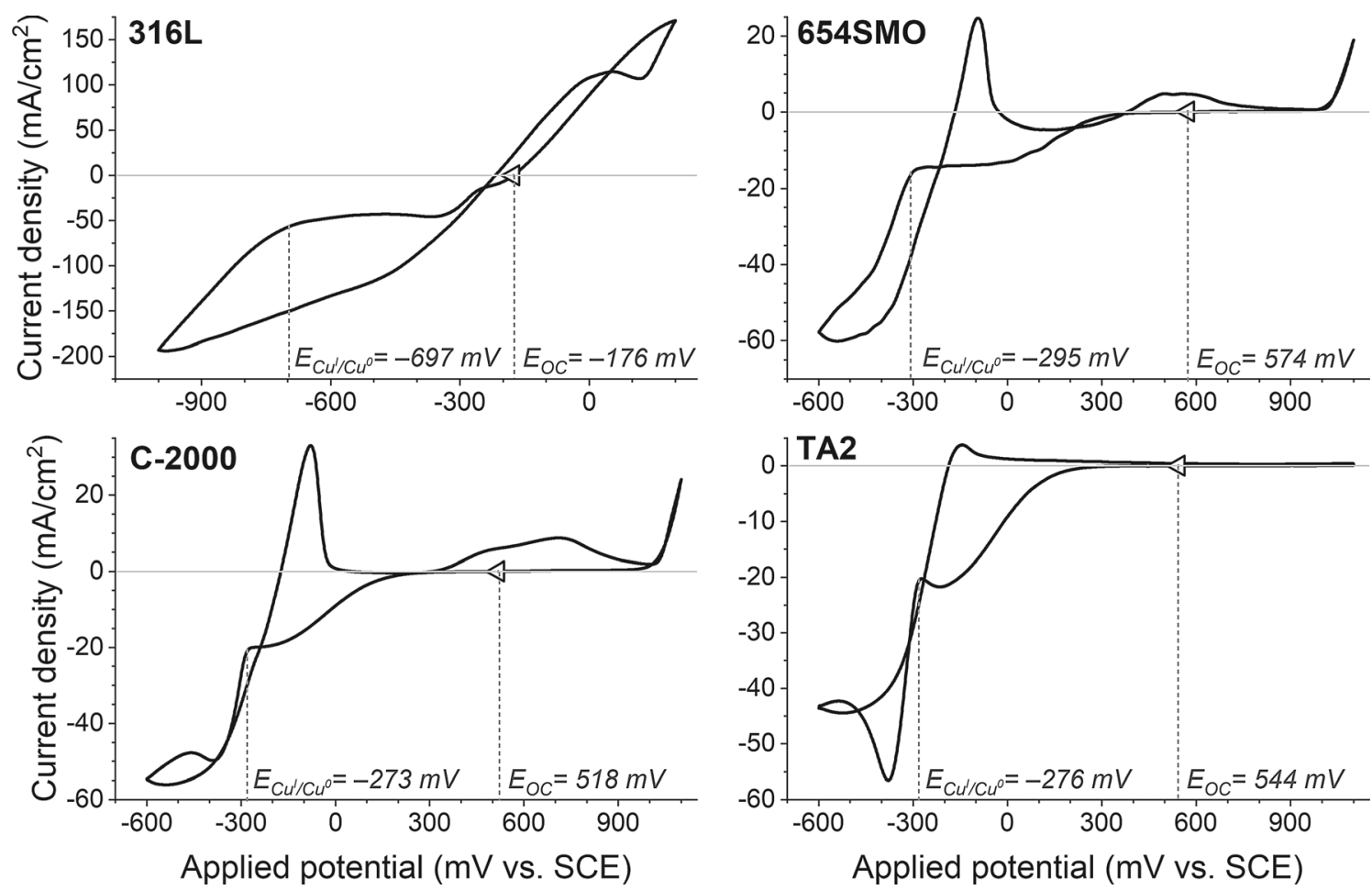

Fig. 6-Voltammograms (average of five cycles) obtained in the process solution with different electrode materials; scan rate $10 \mathrm{mV} / \mathrm{s}$. 
Table VIII. Results of EDRR Experiments

\begin{tabular}{|c|c|c|c|c|c|}
\hline \multirow[b]{2}{*}{ Cathode Material } & \multicolumn{2}{|c|}{ Recovery (Wt Pct) } & \multicolumn{2}{|c|}{ Content (Wt Pct) } & \multirow{2}{*}{$\begin{array}{l}\text { Specific Energy } \\
\text { Consumption }(\mathrm{kWh} / \mathrm{g} \mathrm{Au}\end{array}$} \\
\hline & $\mathrm{Au}$ & $\mathrm{Cu}$ & $\mathrm{Au}$ & $\mathrm{Cu}$ & \\
\hline $316 \mathrm{~L}^{*}$ & 74.4 & 0.6 & - & - & 1.0 \\
\hline $654 \mathrm{SMO}$ & 28.1 & 0.3 & 96.9 & 3.1 & 6.9 \\
\hline C-2000 & 16.9 & 1.0 & 81.2 & 18.8 & 8.2 \\
\hline TA2 & 15.3 & 0.3 & 97.2 & 2.8 & 10.5 \\
\hline Platinum & 29.7 & 0.3 & 98.7 & 1.3 & 4.5 \\
\hline
\end{tabular}

${ }^{*}$ No gold recovered on the cathode.
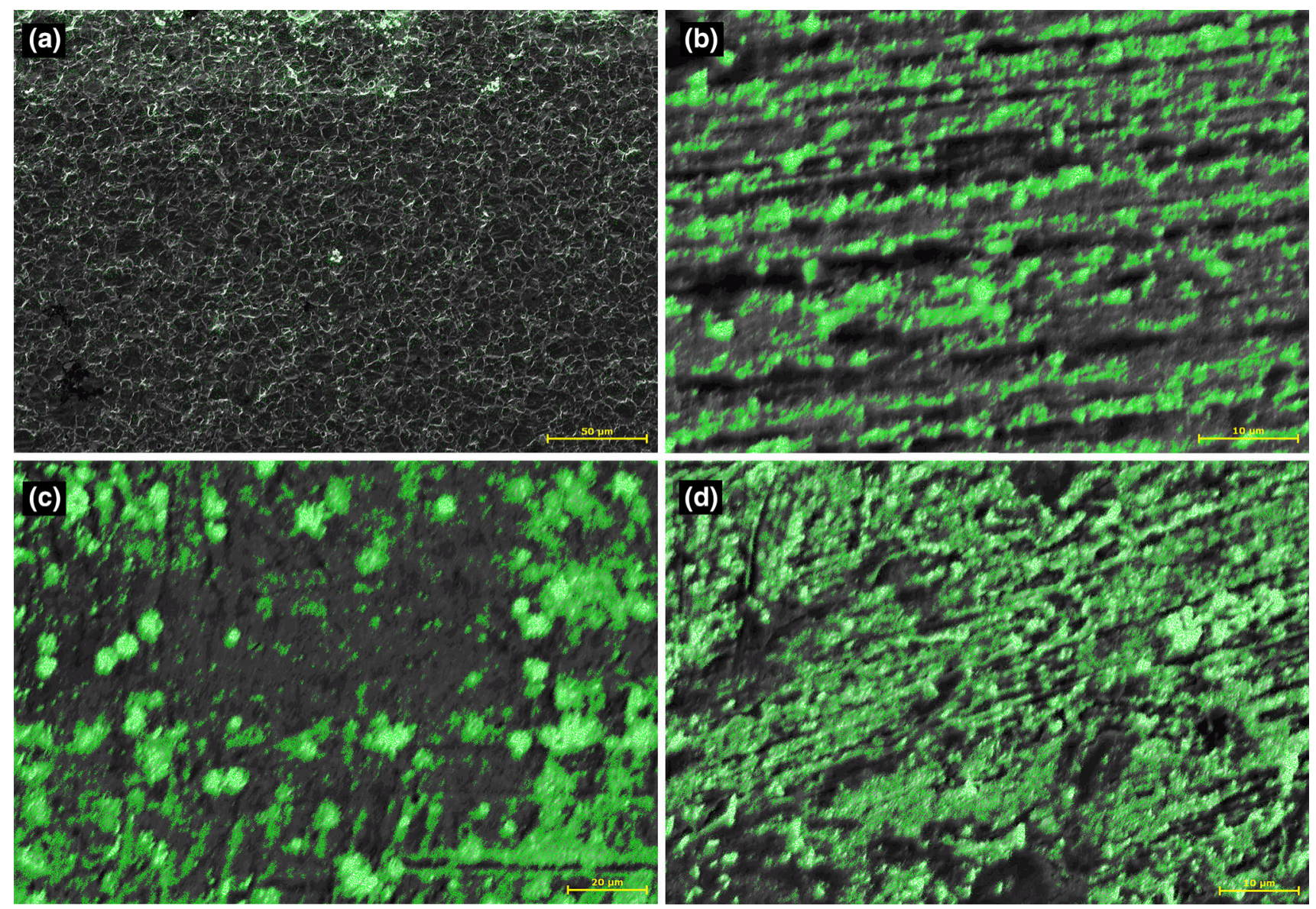

Fig. 7-EDS map of the gold distribution (green) superimposed on the secondary electron image of the cathode surface: (a) 316L, (b) 654SMO, (c) C-2000, and (d) TA2 (Color figure online).

almost uniformly while, at the same time, aligning with the imperfections of the uneven electrode surface. The reason for this is a nonuniform local current distribution at the rough electrode surface that causes preferential deposition of metal along the peaks of the surface topography. ${ }^{[87,88]}$ Surprisingly, the selectivity of the EDRR process with the C-2000 cathode, which is expressed by the content of gold in the final deposit (81.2 pct), was significantly lower than with other materials. A possible explanation is related to the configuration of the passive layer on the electrode-electrolyte interface. According to EIS measurements (Table VII), the C-2000 alloy showed rather thick, porous oxide film in a range of a few micrometers. It would have a detrimental effect on the RR reaction between gold in the solution and electrodeposited copper due to a hindered transport of ions toward the electrode surface, which may have resulted in the higher content of copper in the final deposit (18.8 pct vs approximately 3 pet for 654SMO and TA2).

Further analysis of the EDRR results reveals the relationship between the amount of energy consumed in the EDRR process (Table VIII) and the cathode material. It can be associated with the differences in polarization resistance of the electrode in the process solution, as shown by the LPR measurements. Indeed, 


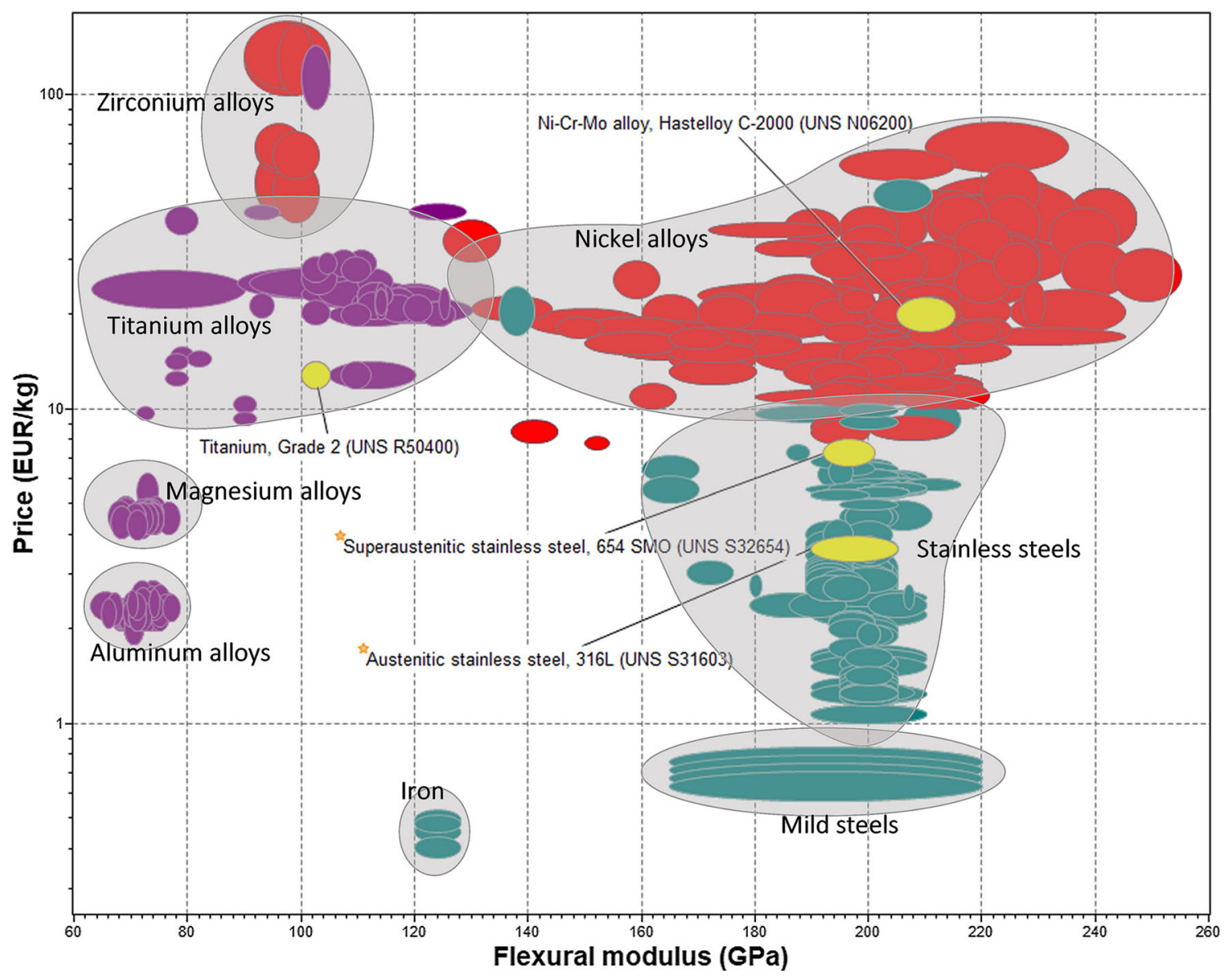

Fig. 8- Ashby chart for the selected material alternatives (from GRANTA EduPack software ${ }^{[95]}$ ).

the maximum value of the specific energy consumption $(10.5 \mathrm{kWh} / \mathrm{g} \mathrm{Au})$ is observed for the TA2 titanium cathode, which also showed the highest polarization resistance (Table IV). Large resistance of the passive layer requires greater overpotential applied in the ED step of the EDRR process; hence, more energy is consumed compared to other materials.

\section{Selection of the Optimum Electrode Material}

In order to make a justified selection of the electrode material for the upscaling of the EDRR process from laboratory to industrial scale, the mechanical properties of the candidate materials have to be taken into account as well as their costs. When permanent cathode blanks are used in the industrial operations of electrowinning or electrorefining, they are typically suspended in the electrolytic cell from the bus bar. ${ }^{[89]}$ In this regard, it is desirable to decrease the weight of the cathode set for minimizing the structural loads. Therefore, the density of the cathode material shall be considered in the material's selection. Furthermore, stripping of the deposited metal from the blank involves bending of the cathode ${ }^{[90]}$ thus, the material of the electrode is required to sustain flexural deformation. The ability of material to resist bending is expressed by the flexural modulus. ${ }^{[91]}$ The Ashby chart in Figure 8 shows the distribution of mechanical properties and prices of different classes of the corrosion-resistant materials, with those investigated in the current work highlighted in yellow. The environmental impact of the consumables (e.g., cathode blanks) accumulates throughout the product life cycle, which affects the overall sustainability of the metallurgical process. ${ }^{[92-94]}$ For this reason, certain attention must be given to the carbon footprint of the materials used as the permanent cathodes in the EDRR process.

Overall, nine material properties were used in the decision-making process. The individual weights of each attribute were calculated by AHP and are given in Table IX. The assigned weighting factors were then used in the TOPSIS technique to rank the alternative materials in order of preference by calculating the Material Performance Index, which equals 1 for the theoretical ideal choice and 0 for the hypothetical worst option. The attributes related to gold recovery on $316 \mathrm{~L}$ were dismissed as the recovery did not take place on the surface but, rather, occurred via precipitation by iron ions released during the $316 \mathrm{~L}$ corrosion process. 
Table IX. Material Properties Used in Multiple Attribute Decision-Making Process

\begin{tabular}{|c|c|c|c|c|c|}
\hline \multirow[b]{2}{*}{ Material Attribute } & \multirow[b]{2}{*}{ Weighting Factor } & \multicolumn{4}{|c|}{ Selection Alternatives } \\
\hline & & $316 \mathrm{~L}$ & $654 \mathrm{SMO}$ & C-2000 & TA2 \\
\hline Rate of corrosion at $25^{\circ} \mathrm{C}(\mathrm{mm} /$ year $)$ & 0.16 & 9.71 & 0.023 & 0.013 & 0.008 \\
\hline Corrosion activation energy $(\mathrm{kJ} / \mathrm{mol})$ & 0.05 & 16.3 & 28.2 & 24.1 & 35.8 \\
\hline Gold recovery (wt pct) & 0.22 & - & 28.1 & 16.9 & 15.3 \\
\hline Purity of the deposit (wt pct Au) & 0.09 & - & 96.9 & 81.2 & 97.2 \\
\hline Specific energy consumption $(\mathrm{kWh} / \mathrm{g})$ & 0.12 & - & 6.9 & 8.3 & 10.5 \\
\hline Flexural modulus (GPa) & 0.04 & 198 & 197 & 210 & 103 \\
\hline Density $\left(\mathrm{g} / \mathrm{cm}^{3}\right)$ & 0.03 & 7.97 & 8.08 & 8.60 & 4.51 \\
\hline Carbon footprint ( $\mathrm{kg} \mathrm{CO} \mathrm{CO}_{2}$-eq. $/ \mathrm{kg}$ ) & 0.08 & 5.6 & 9.9 & 13.2 & 33.3 \\
\hline Price $(€ / \mathrm{kg})$ & 0.21 & 4.1 & 8.2 & 22.6 & 14.5 \\
\hline Material performance index & & 0.35 & 0.90 & 0.61 & 0.66 \\
\hline
\end{tabular}

As seen is Table IX, the 654SMO steel has the highest value of the Material Performance Index, which makes this material the best performing of the four alternatives, whereas the $316 \mathrm{~L}$ steel is ultimately the worst solution. However, the $316 \mathrm{~L}$ steel did not withstand corrosion in the conditions of the EDRR process and, therefore, could be excluded from the decision-making process entirely. Using the TOPSIS method with only three noncorroding materials, the Material Performance Index becomes equal to 0.62 for the 654SMO steel, 0.37 for the C-2000 alloy, and 0.50 for TA2 titanium. Although in this case the 654SMO is less ideal (i.e., Material Performance Index is lower) than in a previous case, it still outperforms other alternatives, which indicates the reliability of this solution for the material selection problem.

The often reported applications for highly alloyed superaustenitic stainless steels, such as 654SMO, are high-temperature, high-chloride environments, which include desalination, ${ }^{[96]}$ pulp and paper mills, ${ }^{[97]}$ biomass combustion ${ }^{[98]}$ exhaust gas cleaning, ${ }^{[99]}$ and geothermal wells, ${ }^{[100,101]}$ among others. Taking into account the composition of cupric chloride leaching solutions used in the EDRR process (Table II) and its acidity $(\mathrm{pH}<2)$, it can be concluded that out of the investigated alternatives, the 654SMO steel is the adequate choice of the electrode material to be used in the scale-up of the EDRR process.

\section{CONCLUSIONS}

The effects of electrode materials on the efficiency of the gold recovery in the EDRR process have been overlooked in previous laboratory work. This corrosion study, for the first time, critically evaluates the choice of cathodes for the distinctive conditions of the EDRR. The material properties databases proved useful in the preliminary screening and selection of material alternatives, and it is their combination with the experimental research that allows for the unequivocal choice of the optimum material for a given application. In the current study, corrosion measurements and gold recovery experiments provided necessary information for a multicriteria decision-making process to identify the most favorable cathode material for the upscaling of the EDRR process of gold recovery. The results of this investigation can be summarized as follows.

1. The $316 \mathrm{~L}$ stainless steel could not sustain the conditions of the acidic chloride environment of the EDRR process $\left(\mathrm{pH}<2,150 \mathrm{~g} / \mathrm{L} \mathrm{Cl}^{-}\right)$, and its corrosion products caused spontaneous reduction of gold in the solution (distant from the cathode surface).

2. Although the insulating oxide film formed on the surface of TA2 titanium warranted excellent corrosion resistance at all investigated temperatures, it also led to the highest specific energy consumption (10.5 $\mathrm{kWh} / \mathrm{g} \mathrm{Au}$ ) in the EDRR experiments among all the materials studied.

3. Good corrosion protection enabled by a porous layer of corrosion products on the C-2000 alloy was shown to limit the efficiency of gold recovery. At the same time, while lower polarization resistance of the 654SMO steel somewhat decreased the corrosion properties of the material, it was beneficial for high gold recovery in the EDRR experiments.

4. A hybrid AHP-TOPSIS approach facilitated the selection of 654SMO as the most suitable cathode material alternative for the EDRR process, which sufficiently satisfies the criteria for corrosion resistance, process efficiency, and cost. In gold recovery EDRR experiments, it achieved the highest efficiency with gold recovery of $28.1 \mathrm{wt}$ pct and a purity of final deposit about 97 pet.

\section{ACKNOWLEDGMENTS}

This research received funding from the European Union Framework Program for Research and Innovation Horizon 2020 under Grant Agreement No. 721385 (EU MSCA-ETN SOCRATES; project website: https://www.etn-socrates.eu). The GoldTail (Grant No. 319691, ML) and NoWASTE (Grant No. 297962, KY) projects funded by the Academy of Finland are greatly acknowledged. The authors thank the laboratory personnel at VTT and Metso Outotec for 
their skillful technical assistance with the experimental work.

\section{CONFLICT OF INTEREST}

On behalf of all the authors, the corresponding author states that there is no conflict of interest.

\section{OPEN ACCESS}

This article is licensed under a Creative Commons Attribution 4.0 International License, which permits use, sharing, adaptation, distribution and reproduction in any medium or format, as long as you give appropriate credit to the original author(s) and the source, provide a link to the Creative Commons licence, and indicate if changes were made. The images or other third party material in this article are included in the article's Creative Commons licence, unless indicated otherwise in a credit line to the material. If material is not included in the article's Creative Commons licence and your intended use is not permitted by statutory regulation or exceeds the permitted use, you will need to obtain permission directly from the copyright holder. To view a copy of this licence, visit http://creativec ommons.org/licenses/by/4.0/.

\section{FUNDING}

Open access funding provided by Aalto University.

\section{REFERENCES}

1. P. Halli, H. Elomaa, B.P. Wilson, K. Yliniemi, and M. Lundström: ACS Sustain. Chem. Eng., 2017, vol. 5, pp. 10996-1004.

2. P. Halli, J.J. Heikkinen, H. Elomaa, B.P. Wilson, V. Jokinen, K. Yliniemi, S. Franssila, and M. Lundström: ACS Sustain. Chem. Eng., 2018, vol. 6, pp. 14631-40.

3. H. Elomaa, P. Halli, T. Sirviö, K. Yliniemi, and M. Lundström: Trans. IMF, 2018, vol. 96, pp. 253-57.

4. M. Lundström, P.-M. Hannula, V. Barranco Asensio, K. Yliniemi, B.P. Wilson, D. Janas, and A. Hubin: in Copper 2019, A. Gharemam and E. Asselin, eds., Canadian Institute of Mining, Metallurgy and Petroleum, Vancouver, BC, Canada, 2019, p. 10.

5. Z. Wang, P. Halli, P.-M. Hannula, F. Liu, B.P. Wilson, K. Yliniemi, and M. Lundström: J. Electrochem. Soc., 2019, vol. 166, pp. E266-74.

6. P. Halli, B.P. Wilson, T. Hailemariam, P. Latostenmaa, K. Yliniemi, and M. Lundström: J. Appl. Electrochem., 2020, vol. 50 , pp. 1-14.

7. I. Korolev, E. Kolehmainen, M. Haapalainen, K. Yliniemi, and M. Lundström: 10th Eur. Metallurgical Conf. (EMC 2019), U. Waschki, ed., GDMB Verlag GmbH, Düsseldorf, Germany, 2019, vol. 2, pp. 623-30.

8. P. Altinkaya, Z. Wang, I. Korolev, J. Hamuyuni, M. Haapalainen, E. Kolehmainen, K. Yliniemi, and M. Lundström: Miner. Eng., 2020, vol. 158, art. no. 106610.

9. K.L. Edwards: Mater. Des., 2005, vol. 26, pp. 469-73.

10. H.M. Tawancy, A. Ul-Hamid, A.I. Mohammed, and N.M. Abbas: Mater. Des., 2007, vol. 28, pp. 686-703.
11. M. Mohammadi, D. Nakhaie, E. Asselin, and A.M. Alfantazi: Eng. Fail. Anal., 2019, vol. 106, art. no. 104183.

12. P.J. Conradie, M.W. Johns, and R.J. Fowles: Hydrometallurgy, 1995, vol. 37, pp. 349-66.

13. D Barnes and TR Raponi: Min. Metall. Explor., 1991, vol. 8, pp. $128-34$

14. JR Arnold and WJ Pennstrom: Min. Metall. Explor., 1987, vol. 4, pp. 65-67.

15. L.A.D. Barbosa, L.G.S. Sobral, and A.J.B. Dutra: Miner. Eng., 2001, vol. 14, pp. 963-74.

16. V. Miettinen, M. Haapalainen, R. Ahtiainen, and J. Karonen: in ALTA 2013 Gold Conf., A. Taylor, ed., ALTA Metallurgical Services, Perth, WA, 2013, pp. 187-202.

17. S. Seisko, M. Lampinen, J. Aromaa, A. Laari, T. Koiranen, and M. Lundström: Miner. Eng., 2018, vol. 115, pp. 131-41.

18. P. Altinkaya, I. Korolev, E. Kolehmainen, M. Haapalainen, and M. Lundström: 10th Eur. Metallurgical Conf. (EMC 2019), U. Waschki, ed., GDMB Verlag GmbH, Düsseldorf, Germany, 2019, vol. 2, pp. 821-29.

19. H.I. Maarof, W.M.A.W. Daud, and M.K. Aroua: Rev. Chem. Eng., 2017, vol. 33, pp. 359-86.

20. Y. Xue and Y. Wang: Green Chem., 2020, vol. 22, pp. 6288-309.

21. M.F.A. Ashby, Y.J.M. Bréchet, D. Cebon, and L. Salvo: Mater. Des., 2004, vol. 25, pp. 51-67.

22. M.F.A. Ashby and K. Johnson: Materials and Design: The Art and Science of Material Selection in Product Design, 3rd ed., Butterworth-Heinemann, Oxford, 2014.

23. R. Sandström: Mater. Des., 1985, vol. 6, pp. 328-38.

24. A. Jahan, M.Y. Ismail, S.M. Sapuan, and F. Mustapha: Mater. Des., 2010, vol. 31, pp. 696-705.

25. A.A.A. Rahim, S.N. Musa, S. Ramesh, and M.K. Lim: Proc. Inst. Mech. Eng. Part L J. Mater. Des. Appl., 2020, vol. 234, pp. 1032-59.

26. T.L. Saaty: Eur. J. Oper. Res., 1990, vol. 48, pp. 9-26.

27. F. Dweiri and F.M. Al-Oqla: Int. J. Comput. Appl. Technol., 2006, vol. 26, pp. 182-89.

28. R. Kumar and S.K. Singal: Renew. Sustain. Energy Rev., 2015, vol. 52 , pp. $240-55$.

29. A. Jahan, F. Mustapha, M.Y. Ismail, S.M. Sapuan, and M. Bahraminasab: Mater. Des., 2011, vol. 32, pp. 1215-21.

30. K. Yoon: Systems Selection by Multiple Attribute Decision Making, Kansas State University, Manhattan, KS, 1980.

31. D.-H. Jee and K.-J. Kang: Mater. Des., 2000, vol. 21, pp. 199-206.

32. H. Zhang, Y. Peng, G. Tian, D. Wang, and P. Xie: PLoS ONE, 2017, vol. 12, art. no. e 0177578 .

33. L. Anojkumar, M. Ilangkumaran, and M. Vignesh: Int. J. Mater. Prod. Technol., 2015, vol. 51, pp. 102-26.

34. R.V. Rao and J.P. Davim: Int. J. Adv. Manuf. Technol., 2008, vol. 35 , pp. 751-60.

35. E. Lacasa, S. Cotillas, C. Saez, J. Lobato, P. Cañizares, and M.A. Rodrigo: Curr. Opin. Electrochem., 2019, vol. 16, pp. 149-56.

36. Metals and Alloys in the Unified Numbering System (UNS), 13th ed., SAE International, Warrendale, PA, 2017.

37. R. von Bonsdorff, J. Aromaa, O. Forsén, O. Hyvärinen, and M.H. Barker: 3rd Eur. Metallurgical Conf. (EMC 2005), U. Waschki, ed., GDMB Verlag GmbH, Dresden, Germany, 2005, pp. $237-45$.

38. M. Lampinen, S. Seisko, O. Forsström, A. Laari, J. Aromaa, M. Lundström, and T. Koiranen: Hydrometallurgy, 2017, vol. 169, pp. 103-11.

39. $\mathrm{P}$ Altinkaya, JP Liipo, E Kolehmainen, $\mathrm{M}$ Haapalainen, $\mathrm{M}$ Leikola, and M Lundström: Min. Metall. Explor., 2019, vol. 36, pp. 335-42.

40. ASTM G1-03(2017)E1. Standard Practice for Preparing, Cleaning, and Evaluating Corrosion Test Specimens, ASTM International, West Conshohocken, PA, 2017.

41. R. Qvarfort: Corros. Sci., 1988, vol. 28, pp. 135-40.

42. J. Jankowski and R. Juchniewicz: Corros. Sci., 1980, vol. 20, pp. $841-51$

43. V.S. Beleevskii, K.A. Konev, V.V. Novosadov, and V.Y. Vasilev: Prot. Met., 2004, vol. 40, pp. 566-69.

44. M. Stern and A.L. Geary: J. Electrochem. Soc., 1957, vol. 104, art. no. 56 . 
45. ASTM G102-89(2015)E1. Standard Practice for Calculation of Corrosion Rates and Related Information from Electrochemical Measurements, ASTM International, West Conshohocken, PA, 2015.

46. F. Mansfeld, S. Lin, Y.C. Chen, and H. Shih: J. Electrochem. Soc., 1988, vol. 135, pp. 906-907.

47. A.T. Tran, F. Huet, K. Ngo, and P. Rousseau: Electrochim. Acta, 2011, vol. 56, pp. 8034-39.

48. M. Lundström, K. Yliniemi: World Intellectual Property Organization, Geneva, WO2017216417, 2017.

49. M. Lundström, R. Ahtiainen, P. Laihonen, and M. Lindgren: ALTA 2015 Gold \& Precious Metals Conf., A. Taylor, ed., ALTA Metallurgical Services, Perth, WA, Australia, 2015, pp. 269-80.

50. J. Liu, A.M. Alfantazi, and E. Asselin: Corrosion, 2015, vol. 71, pp. 352-66.

51. A. Guyader, F. Huet, and R.P. Nogueira: Corrosion, 2009, vol. 65 , pp. $136-44$

52. Z.H. Jin, H.H. Ge, W.W. Lin, Y.W. Zong, S.J. Liu, and J.M. Shi: Appl. Surf. Sci., 2014, vol. 322, pp. 47-56.

53. B. Yang, C. Shi, Y. Li, Q. Lei, and Y. Nie: J. Mater. Res., 2018, vol. 33, pp. 3801-808.

54. W. Faes, S. Lecompte, J. van Bael, R. Salenbien, R. Bäßler, I. Bellemans, P. Cools, N. de Geyter, R. Morent, K. Verbeken, and M. de Paepe: Geothermics, 2019, vol. 82, pp. 182-89.

55. O. Forsén, J. Aromaa, and M. Tavi: Mater. Sci. Forum, 1995, vols. $192-194$, pp. 41-52

56. Y Yi, P Cho, A Al Zaabi, Y Addad, and C Jang: Corros. Sci., 2013, vol. 74, pp. 92-97.

57. I. Betova, M. Bojinov, T. Laitinen, K. Mäkelä, P. Pohjanne, and T. Saario: Corros. Sci., 2002, vol. 44, pp. 2675-97.

58. X. Zhang, D. Zagidulin, and D.W. Shoesmith: Electrochim. Acta, 2013, vol. 89, pp. 814-22.

59. Y. Liu, R.F. Schaller, and E. Asselin: J. Electrochem. Soc., 2019, vol. 166, pp. C76-82.

60. M.O. Bodunrin, L.H. Chown, J.W. van der Merwe, K.K. Alaneme, C. Oganbule, D.E.P. Klenam, and N.P. Mphasha: Corros. Rev., 2020 , vol. 38 , pp. $25-47$.

61. M. Slemnik: Mater. Des., 2016, vol. 89, pp. 795-801.

62. E. Peters: $J O M, 1991$, vol. 43, pp. 20-26.

63. M.A. Maleeva, A.A. Rybkina, A.I. Marshakov, and V.V. Elkin: Prot. Met., 2008, vol. 44, pp. 548-56.

64. A. Fattah-Alhosseini, A. Saatchi, M.A. Golozar, and K. Raeissi: Electrochim. Acta, 2009, vol. 54, pp. 3645-50.

65. Z. Kerner and T. Pajkossy: J. Electroanal. Chem., 1998, vol. 448, pp. 139-42.

66. J.-P. Diard, B. Le Gorrec, and C. Montella: J. Electroanal. Chem., 1992, vol. 326, pp. 13-36.

67. L. Bai and B.E. Conway: Electrochim. Acta, 1993, vol. 38, pp. $1803-15$.

68. F. Mohammadi, T. Nickchi, M.M. Attar, and A.M. Alfantazi: Electrochim. Acta, 2011, vol. 56, pp. 8727-33.

69. C. Boissy, B. Ter-Ovanessian, N. Mary, and B. Normand: Electrochim. Acta, 2015, vol. 174, pp. 430-37.

70. N. Cotolan, A. Pop, D. Marconi, O. Ponta, and L.M. Muresan: Mater. Corros., 2015, vol. 66, pp. 635-42.

71. C.H. Hsu and F. Mansfeld: Corrosion, 2001, vol. 57, pp. 747-48.

72. B. Hirschorn, M.E. Orazem, B. Tribollet, V. Vivier, I. Frateur, and M. Musiani: Electrochim. Acta, 2010, vol. 55, pp. 6218-27.

73. I. Frateur: ECS Trans., 2008, vol. 13, pp. 115-28.

74. A. Di Paola: Electrochim. Acta, 1989, vol. 34, pp. 203-10.

75. N.B. Hakiki, S. Boudin, B. Rondot, and M. da Cunha Belo: Corros. Sci., 1995, vol. 37, pp. 1809-22.
76. G. Barral, F. Njanjo-Eyoke, and S. Maximovitch: Electrochim. Acta, 1995, vol. 40, pp. 2815-28.

77. A. Fattah-Alhosseini, M. Naseri, S.O. Gashti, S. Vafaeian, and M.K. Keshavarz: Corros. Sci., 2018, vol. 131, pp. 81-93.

78. T. Shibata and Y.C. Zhu: Corros. Sci., 1995, vol. 37, pp. 133-44.

79. M. Doulache, M. Trari, and A. Benchettara: Prot. Met. Phys. Chem. Surf., 2014, vol. 50, pp. 200-08.

80. J. Pan, D. Thierry, and C. Leygraf: Electrochim. Acta, 1996, vol. 41 , pp. $1143-53$.

81. J. Pan, C. Leygraf, R.F.A. Jargelius-Pettersson, and J. Lindén: Oxid. Met., 1998, vol. 50, pp. 431-55.

82. N.S. Zadorozne, M.A. Rodríguez, R.M. Carranza, N.S. Meck, and R.B. Rebak: in Corrosion 2010, NACE International, San Antonio, TX, 2010, art. no. 10236.

83. K. Yliniemi, Z. Wang, I. Korolev, P.-M. Hannula, P. Halli, and M. Lundström: ECS Trans., 2018, vol. 85, pp. 59-67.

84. I. Korolev, P. Altinkaya, P. Halli, P.-M. Hannula, K. Yliniemi, and M. Lundström: J. Clean. Prod., 2018, vol. 186, pp. 840-50.

85. I. Korolev, S. Spathariotis, K. Yliniemi, B.P. Wilson, A.P. Abbott, and M. Lundström: Green Chem., 2020, vol. 22, pp. 361525.

86. M. Wojnicki, K. Fitzner, and M. Luty-Błocho: Trans. Nonferrous Met. Soc. China, 2015, vol. 25, pp. 2027-36.

87. Y.D. Gamburg and G. Zangari: Theory and Practice of Metal Electrodeposition, Springer, New York, NY, 2011, pp. 169-87.

88. Z. Zeng, P. Barai, S.Y. Lee, J. Yang, X. Zhang, W. Zheng, Y.S. Liu, K.C. Bustillo, P. Ercius, J. Guo, Y. Cui, V. Srinivasan, and H. Zheng: Nano Energy, 2020, vol. 72, p. 104721.

89. L.H. Nordlund and H.K. Virtanen: 7th Southern African Base Metals Conf., P. den Hoed, ed., Southern African Institute of Mining and Metallurgy, Mpumalanga, South Africa, 2013, pp. 89-98.

90. N.J. Aslin, O. Eriksson, G.J. Heferen, and G. Sue Yek: in Copper 2010, J. Harre, ed., GDMB Verlag GmbH, Hamburg, Germany, 2010, vol. 4, pp. 1253-70.

91. ASTM E290-14. Standard Test Methods for Bend Testing of Material for Ductility, ASTM International, West Conshohocken, PA, 2014.

92. C. Chen: Manage. Sci., 2001, vol. 47, pp. 250-63.

93. M.F.A. Ashby: Materials and the Environment: Eco-Informed Material Choice, 2nd ed., Butterworth-Heinemann, Oxford, 2012.

94. I. Rönnlund, M.A. Reuter, S. Horn, J. Aho, M. Aho, M. Päällysaho, L. Ylimäki, and T. Pursula: Int. J. Life Cycle Assess., 2016, vol. 21, pp. 1719-48.

95. GRANTA EduPack [Software], Granta Design Ltd., Cambridge, 2020.

96. A.U. Malik, S. Ahmad, I. Andijani, and S. Al-Fouzan: Desalination, 1999, vol. 123, pp. 205-13.

97. A. Riihimäki and R. Paley: World Pumps, 2005, vol. 470, pp. 2627.

98. R.A. Antunes and M.C. Lopes de Oliveira: Corros. Sci., 2013, vol. 76 , pp. 6-26.

99. E. Aragon, J. Woillez, C. Perice, F. Tabaries, and M. Sitz: Mater. Des., 2009, vol. 30, pp. 1548-55.

100. H. Sarmiento Klapper, R. Bäßler, K. Weidauer, and D. Stuerzbecher: Corrosion, 2012, vol. 68, art. no. 016001.

101. A. Stoljarova, S. Regenspurg, and R. Bäßler: Corrosion 2019, NACE International, Nashville, TN, 2019, art. no. 12862.

Publisher's Note Springer Nature remains neutral with regard to jurisdictional claims in published maps and institutional affiliations. 